\title{
Study on the Phenol Removal for the Security of Water Quality in Rural Areas
}

\author{
Takeo NAKAMURA*, Tamotsu MIYOSHI*, Seiki TANADA* \\ and Tatsumi TOUMIYA*
}

\begin{abstract}
For the security of water quality in rural areas, adsorption removal of phenol which is one of disinfectants for excretions by six kinds of commercial activated carbon was investigated.

At equilibrium concentration of 1 and $10 \mathrm{ppm}$, activated carbon indicated $\mathrm{pH} 10.19$ adsorbed phenol as much as 2.17 and 1.84 times compared with activated carbon indicated $\mathrm{pH} 3.06$, respectively. At low equilibrium concentration of phenol, the amount adsorbed was significantly influenced by surface $\mathrm{pH}$ of activated carbon $(\mathrm{p}<0.05)$.

These results suggest that the difference in amount of phenol adsorbed onto activated carbon is due to the interaction between phenol and surface oxygen groups on the adsorbent. Therefore, it is concluded that the activated carbon of which surface is basic suitable for the adsorption removal of phenol in the agricultural waste waters.
\end{abstract}

(1) agricultural waste water treatment (2) security of water quality (3) phenol (4) adsorption removal (5) activated carbon

\section{INTRODUCTION}

In recent years, the progress of water pollution is remarkable in rivers and irrigation ponds, that is the agricultural water sources. The water pollution for irrigation has been spread not only in urban areas but also in rural areas. The water pollution in rural areas give rise to problems in life environment and labor hygienic environment. Therefore, the security of water quality in rural area is a serious problems ${ }^{11}$.

In rural areas, phenol has been used for disinfecting excretions in concentration from 3 to $5 \%$. If phenol, however, flow into the water source and water for drinking is disinfected by chlorine, phenol is chlorinated and produce chlorophenols, a stenchy substance. Consequently, the drinking water is sometimes given a decision as unsuitable for drinking ${ }^{2)}$.

In general, the activated sludge method has been taken the waste water treatment. However, its drawback is that the constituent of disinfectants such as phenol hinder the purification abilities of aerobic bacteria. If phenol are not decomposed by bacteria and are liberated in an unchanged form, they produce chlorophenols and it cause a bad smell and stale taste in drinking water.

It is effective to use a solid adsorbent such as activated carbon for removing pollutants in waste water ${ }^{3)}$.

The water pollution arised from various pollutants in waste water is a serious problem in both urban areas and rural areas.

This work was investigated with a view to elucidating the characteristics of adsorption removal of phenol, one of disinfectants, onto activated carbon for the security of water quality in rural areas.

\section{MATERIALS AND METHODS}

\section{Materials}

Phenol used as an adsorbate was an extra-pure 
reagent (Wako Pure Chemical Industries Company, Ltd.), and it was more than $99 \%$ pure. Six kinds of activated carbon were obtained from commercial sources, and their particle size were $4-8$ mesh. Before use, activated carbons were washed by distilled water until carbon particle were not observed. They were dried at $110^{\circ} \mathrm{C}$ for $48 \mathrm{hrs}$, and then kept in a desiccator.

Procedure for Adsorption Equilibrium Isotherms

Adsorption equilibrium isotherms were obtained for the phenol-water/adsorbent system. A weighed amount of activated carbon, $0.1-0.5 \mathrm{~g}$, was shaken with $50 \mathrm{ml}$ of phenol solution of ca. 500-4000 $\mathrm{ppm}$ at a constant temperature of $25^{\circ} \mathrm{C}$.It took 4 days to attain equilibrium adsorption with constant shaking. After equilibration, phenol concentration in the supernatant solutions were measured at $270 \mathrm{~nm}$ using a spectrophotometer (Hitachi model 101).

Pore size Distribution and Specific Surface Area

Pore size distribution of activated carbon was measured by the method described previously ${ }^{4}$. Specific surface area of activated carbon was measured by means of the B.E. T. method ${ }^{4)}$.

\section{Surface $\mathrm{pH}$ and Base Consumption}

The method for measuring surface $\mathrm{pH}$ of activated carbon was that given by Urano, et $\mathrm{al}^{5}$. Base consumption of activated carbon was measured as follows ${ }^{6)}$; a weighed amount of activated carbon, $1.0 \mathrm{~g}$, was shaken with $50 \mathrm{ml}$ of 0.01 normal sodium hydroxide solution at $25^{\circ} \mathrm{C}$ for $24 \mathrm{hrs}$. Then

Table 1. Physicochemical Properties of Activated Carbon

\begin{tabular}{rrrrrr}
\hline & $\begin{array}{c}\text { Specific } \\
\text { No. } \\
\begin{array}{c}\text { Area } \\
\left(\mathrm{m}^{2} / \mathrm{g}\right)\end{array}\end{array}$ & $\begin{array}{c}\text { Pore Volume } \\
(\mathrm{ml} / \mathrm{g})\end{array}$ & $\begin{array}{c}\text { Surface } \\
\mathrm{r}<100 \AA\end{array}$ & $\begin{array}{c}\mathrm{NaOH} \\
\mathrm{r}<14.5 \AA\end{array}$ & $\begin{array}{c}\text { Consumption } \\
(\mathrm{mmol} / \mathrm{g})\end{array}$ \\
\hline 1 & 976.76 & 0.586 & 0.338 & 3.06 & 0.613 \\
2 & .813 .69 & 0.485 & 0.399 & 6.37 & 0.147 \\
3 & 1220.54 & 0.535 & 0.418 & 6.41 & 0.173 \\
4 & 931.08 & 0.592 & 0.460 & 8.82 & 0.040 \\
5 & 1093.24 & 0.600 & 0.533 & 10.19 & 0.065 \\
6 & 692.18 & 0.424 & 0.364 & 10.19 & 0.160 \\
\hline
\end{tabular}

the amount of residual sodium hydroxide was determined by titration with 0.01 normal hydrochloric acid.

\section{RESULTS}

Physicochemical properties of activated carbon are shown in Table 1. It may say that specific surface area and pore volume are physical factors, and surface $\mathrm{pH}$ and base consumption are chemical factors. On physical factors, the surface area of No. 6 was the smallest and its value was approximately $57 \%$ of No. 3. On the whole, surface area of activated carbon used was about $1000 \mathrm{~m}^{2} / \mathrm{g}$ except for No. 6 . The significant difference of pore volume with pore radius less than $100 \AA$ of each activated carbon was not found. The proportions of micro pore volume $(\mathrm{r}<14.5 \AA)$ to pore volume $(\mathrm{r}<100 \AA)$ of Nos. 2 -6 were approximately $80 \%$. That proportion of No. 1 was $57.7 \%$.

On the oher hand, surface $\mathrm{pH}$ of activated carbon was widely distributed. No. 1 was acidic, Nos. 2-3 were neutral and Nos. $4-6$ were basic. Sodium hydroxide consumption was inversely proportional to surface $\mathrm{pH}$ of activated carbon.

Figure 1 shows adsorption isotherms of phenol onto activated carbon at $25^{\circ} \mathrm{C}$. The logarithm of amount adsorbed was plotted linearly against the logarithm of equilibrium concentration. The adsorption of phenol onto activated carbon was of Freundlich type. The Freundlich equation can be expressed

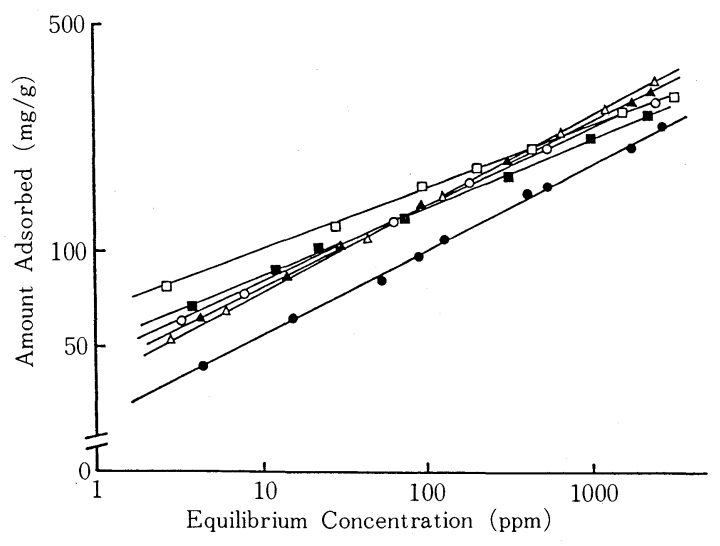

Fig. 1 Adsorption Isotherm of Phenol onto Activated Carbon at $25^{\circ} \mathrm{C}$.

$\bullet$, No. 1 ; $\mathrm{O}$, No. 2 ; $\boldsymbol{\Lambda}$, No. 3 ; $\triangle$, No. 4 凹, №. $5 ; \square$, №. 6 . 
in the following form,

$$
\log V=1 / n \log C+\log k \text {, }
$$

where $\mathrm{V}$ is amount adsorbed, $\mathrm{C}$ is equilibrium concentration, and $\mathrm{n}$ and $\mathrm{k}$ are constants. At each equilibrium concentration, amount of phenol adsorbed onto No. 1 was lower than those onto Nos. 2-6. At low equilibrium concentration of phenol (less than approximately $70 \mathrm{ppm}$ ), Nos. $5-6$ showed a high amount of phenol adsorbed. In the range of less than appoximately $400 \mathrm{ppm}$, No. 6 is the prefered adsorbent for removing phenol from a liquid phase.

The Freundlich constant and equilibrium amount adsorbed at each equilibrium concentration are shown in Table 2. The amount adsorbed was determined by an isotherm run. All the $1 / \mathrm{n}$ values of phenol onto activated carbon were in the range of 0.194 to 0.265 . A marked difference of $1 / \mathrm{n}$ value was not found in Nos. 1-6. Activated carbon No. 1 showed the smallest $\mathrm{k}$ value of the Freundlich equation. Its value was below $1 / 2$ of that of No. 6 . The amount adsorbed at 10 and $100 \mathrm{ppm}$ of equilibrium concentration showed a similar tendency to that at $1 \mathrm{ppm}$, that is, the $\mathrm{k}$ value of the Freundlich equa tion. At $1000 \mathrm{ppm}$, No. 1 adsorbed the smallest amount of phenol and No. 3 adsorbed the highest amount. The degree of the difference in the amount adsorbed onto each activated carbon become small with increasing equilibrium concentration. The difference of amount of phenol adsorbed between adsorbent indicating the smallest amount adsorbed and highest amount adsorbed was 2.2, 1.8, 1.6 and 1.4 times at equilibrium concentration of $1,10,100$ and $1000 \mathrm{ppm}$, respectively.

Table 2. Freundlich Constants and Equilibrium Amount of Phenol Adsorbed

\begin{tabular}{cccccccc}
\hline & \multicolumn{3}{c}{ Freundlich Constant } & & \multicolumn{3}{c}{ Amount Adsorbed $(\mathrm{mg} / \mathrm{g})$} \\
\cline { 5 - 7 } No. & $1 / \mathrm{n}$ & $\begin{array}{c}\mathrm{k} \\
(\mathrm{mg} / \mathrm{g})\end{array}$ & & $\begin{array}{l}\mathrm{Q}_{\infty} \text { at } \\
10 \mathrm{ppm}\end{array}$ & $\begin{array}{l}\mathrm{Q}_{\infty} \text { at } \\
100 \mathrm{ppm}\end{array}$ & $\begin{array}{c}\mathrm{Q}_{\infty} \text { at } \\
1000 \mathrm{ppm}\end{array}$ \\
\hline 1 & 0.265 & 30.211 & & 55.571 & 102.219 & 188.026 \\
2 & 0.248 & 44.209 & & 78.297 & 138.668 & 245.589 \\
3 & 0.259 & 43.332 & & 78.692 & 142.905 & 259.516 \\
4 & 0.261 & 42.196 & & 76.945 & 140.312 & 255.862 \\
5 & 0.214 & 50.841 & & 83.231 & 136.257 & 223.065 \\
6 & 0.194 & 65.446 & 102.230 & 159.691 & 249.448 \\
\hline
\end{tabular}

The amount of activated carbon for 90\% removal of phenol is shown in Table 3. The amount for $90 \%$ removal in the initial phenol concentration of $1000 \mathrm{ppm}$ was the largest amount for No. 1 and the smallest amount for No. 6 . The difference of the amount of activated carbon for Nos. 2-5 was not found. When the initial concentration is $100 \mathrm{ppm}$, the amount of activated carbon was also the largest for No. 1 and the smallest amount for No. 6. The amount of No. 1 for $90 \%$ removal of phenol was 1 . 84 times as much as that of No. 6 . When the initial concentration is $10 \mathrm{ppm}$, the amount of No. 6 for $90 \%$ removal was less than $1 / 2$ as much as that of No. 1. In adsorption removal of phenol, it was resulted that activated carbon No. 6 was the most preferred adsorbent for the removal of phenol.

In figure 2, the relationship between amount of phenol adsorbed and specific surface area, and in figure 3, the relationship between amount adsorbed and adsorption pore (micro pore) volume are shown. It was not found the significant correlation between amount of phenol adsorbed and physical factors of activated carbon. In figure 4 , the relationship between amount adsorbed and surface $\mathrm{pH}$, and in figure 5 , the relationship between amount adsorbed and sodium hydroxide consumption are shown. It was found the significant correlation between amount of phenol adsorbed and chemical factors of activated carbon. The correlation coefficients between amount of phenol adsorbed and physical or chemical factors of adsorbent are calculated and the results are shown in Table 4 . At low equilibrium concentration (less than $10 \mathrm{ppm}$ ), a significant difference was recognized $(p<0.05)$ between amount of

Table 3. Amount of Activated Carbon for $90 \%$ Removal of Phenol.

\begin{tabular}{|c|c|c|c|}
\hline \multirow{2}{*}{ No. } & \multicolumn{3}{|c|}{ Amount of Activated Carbon (g) } \\
\hline & \multicolumn{3}{|c|}{$1000 \mathrm{ppm}-$} \\
\hline 1 & 8.805 & 1.620 & 0.298 \\
\hline 2 & 6.490 & 1.149 & 0.204 \\
\hline 3 & 6.300 & 1.144 & 0.208 \\
\hline 4 & 6.414 & 1.170 & 0.213 \\
\hline 5 & 6.605 & 1.081 & 0.177 \\
\hline 6 & 5.636 & 0.880 & 0.138 \\
\hline
\end{tabular}




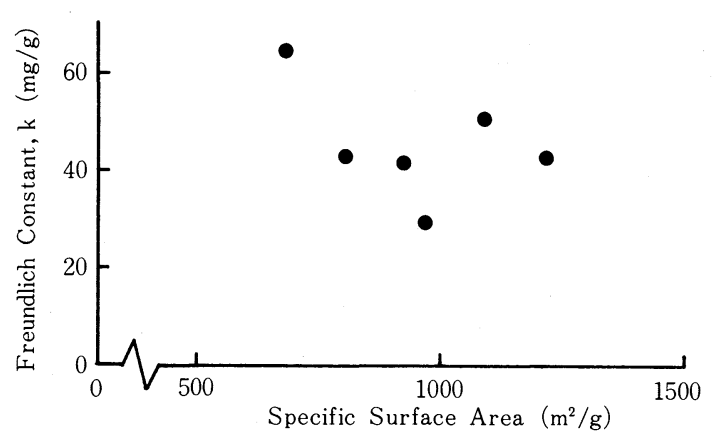

Fig. 2 Relationship between $\mathrm{k}$ value and Specific Surface Area.

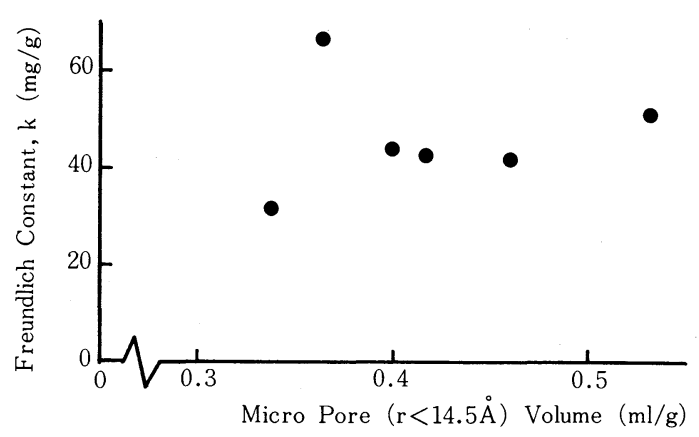

Fig. 3 Relationship between $\mathrm{k}$ value and Micro Pore Volume.

Table 4. Correlation Coefficient of Physicochemical Properties of Activated Carbon and Amount of Phenol Adsorbed.

\begin{tabular}{|c|c|c|c|c|c|}
\hline \multirow{2}{*}{$\begin{array}{l}\text { Amount } \\
\text { Adsorbed }\end{array}$} & \multirow{2}{*}{$\begin{array}{l}\text { Specific } \\
\text { Surface } \\
\text { Area }\end{array}$} & \multicolumn{2}{|c|}{ Pore Volume } & \multirow{2}{*}{$\begin{array}{c}\text { Surface } \\
\mathrm{pH}\end{array}$} & \multirow{2}{*}{$\begin{array}{l}\mathrm{NaOH} \\
\text { Con- } \\
\text { sumption }\end{array}$} \\
\hline & & $\mathrm{r}<100 \AA$ & $\mathrm{r}<14.5 \AA$ & & \\
\hline $\begin{array}{c}Q_{\infty} \text { at } \\
1 \mathrm{ppm}\end{array}$ & -0.471 & -0.677 & +0.158 & $+0.840^{*}$ & -0.589 \\
\hline $\begin{array}{l}Q_{\infty} \text { at } \\
10 \mathrm{ppm}\end{array}$ & -0.427 & -0.681 & +0.197 & $+0.854^{*}$ & -0.692 \\
\hline $\begin{array}{l}Q_{\infty} \text { at } \\
10^{2} \mathrm{ppm}\end{array}$ & -0.318 & -0.637 & +0.239 & +0.803 & -0.808 \\
\hline $\begin{array}{l}Q_{\infty} \text { at } \\
10^{3} \mathrm{ppm}\end{array}$ & -0.081 & -0.432 & +0.238 & +0.543 & -0.806 \\
\hline
\end{tabular}

* Significantly different $(p<0.05)$

phenol adsorbed and surface $\mathrm{pH}$ of activated car. bon.

\section{DISCUSSION}

A conventional counterplan for waste water

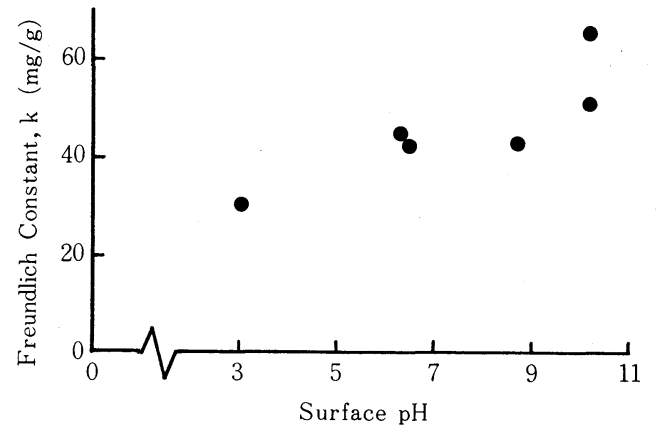

Fig. 4 Relationship between $k$ value and Surface $\mathrm{pH}$.

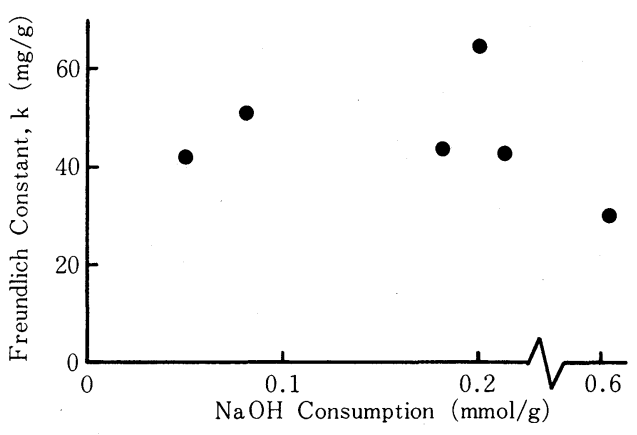

Fig. 5 Relationship between $\mathrm{k}$ value and $\mathrm{NaOH}$ Consumption.

treatment have been centered in manufacturing industry, because the industrial waste water has been regulated by Water Pollution Control $\mathrm{Law}^{7}$. However it has been delayed for the waste water treatment in rural areas. One of the reason is that waste had been used to utilize for manure, however, the advanced economic growth in recent years cause the decrease of agricultural work force and supply of chemical fertilizer shut the way of waste reutilization ${ }^{1}$.

The adsorption capacity of activated carbon for organic pollutants is dominated by pore structure $^{8-10)}$. The more the pore with a minimum diameter that adsorbate can invade exist, the greater the amount adsorbed is ${ }^{8}$. According to Singh ${ }^{11}$, the area that one molecule of phenol occupid is $28 \AA^{2}$, and if phenol molecule is spherical, the minium diamater of pore that a phenol molecule can invade is about $6 \AA$. Asakawa, et $\mathrm{al}^{12)}$ reported that its diameter is $5.3 \AA$. From these values, it is estimated that an activated carbon which be rich in 
micro pore volume indicates a large amount of phenol adsorbed. According to our result, however, the amount of phenol adsorbed in low concentration is significantly influenced by surface $\mathrm{pH}$ of activated carbon.

Activated carbon frequently contains hetero atoms such as oxygen, nitrogen and hydrogen. These hetero atoms may affect the adsorption capacity of activated carbon. Moreover, it is known the existence of surface oxygen groups on carbon, and the effect of surface oxygen groups on amount adsorbed is not neglected ${ }^{13)}$. It is reported that the contents of surface oxygen groups on carbon are related to surface $\mathrm{pH}^{14)}$. Graham ${ }^{15)}$ reported that acidic chemisorbed oxygen on carbon can play a very significant role in adsorption from an aqueous solution.

In liquid phase adsorption, phenol and water molecules are competitively adsorbed on adsorbent. The water molecules are adsorbed selectively to surface oxygen groups and form an aggregate by hydrogen bonding on carbon because of its large polarity ${ }^{16)}$. When the concentration of phenol is low, it is easy to form aggregates. Therefore, it is thought that aggregates of water molecules on activated carbon prevent the invasion of phenol into micro pores.

It is concluded that at low equilibrium concentration, the amount of phenol adsorbed is firstly influenced by the surface chemical factors of activated carbon such as surface $\mathrm{pH}$ and base consumption. When the equilibrium concentration increases, the effect of the pore structure factors on amount adsorbed gradually appeared.

\section{CONCLUSION}

The adsorption removal of phenol, one of disinfectants, onto six kinds of commercial activated carbon for the security of water quality in rural areas was investigated.

The relationship between amount of phenol adsorbed and physical factors of activated carbon was not significantly. Preferably, it was recognized the significant correlation between amount of phe- nol adsorbed and chemical factors of activated carbon.

\section{REFERENCES}

1) Masujima $\mathrm{H}$ : Problems on Treatment of Rural Effluents. Kogai to Taisaku 21: 1066-1071, 1985

2) Nippon Kagakukai : Environment Preservation. Kagaku Binran (ouyo-hen) p1442, 1980

3) Urano K: Waste Water Treatment by Activated Carbon. Yuki Gosei Kagaku Kyoukaishi 33 : 333-341, 1975

4 ) Boki K : Studies on the Adsorption Removal of Hydrogen Sulfide Gas Static and Dynamic Adsorption Characteristics of Hydrogen Sulfide in Gaseous Phase on Porous Activated Carbons and Zeolites. Jpn. J. Hyg 32 : 482-493, 1977

5) Urano K, Sonai M, Nakayama R and Kobayashi $Y$ : Adsorption Mechanism of Strong Acids, Strong Bases or their Salts by Activated Carbon and $\mathrm{pH}$ of the Solution with Carbon Suspension. Nippon Kagaku Kaishi 1976 : 1773-1778

6) Boehm H P, Diehl E, Heck W and Sappok R: Surface Oxides of Carbon. Angew. Chem. Internat. Edit 3: 669 $-677,1964$

7) Hayashi T: Water Pollution Control in Japan. J. Water Pollut. Contr. Fed 52: 850-861, 1980

8) Abe I, Hayashi K and Kitagawa M: Adsorption of Nonionic Surfactants. Yukagaku 25: 145-150, 1976

9) Puri B R, Bhardwaj S S and Gupta U: Adsorption of Phenol from Aqueous Solutions by Carbons in Relation to Their Specific Surface Areas. J. Indian Chem. Soc 53 : 1095-1098, 1976

10) Giusti D M, Conway R A and Lawson C T : Activated Carbon Adsorption of Petrochemicals. J. Water Pollut. Contr. Fed 46: 947-965, 1974

11) Singh D D: Surface Orientation of Phenol Molecules adsorbed from Aqueous Solution by Carbon Blacks. Indian J. Chem 9 : 1369-1371, 1971

12) Asakawa $T$ and Ogino $K$ : Removal of Trace Organic Compounds in Water by Surface-modified Carbon Adsorbents. TANSO $123: 143-149,1985$

13) Coughlin R W and Ezra F S : Role of Surface Acidity in the Adsorption of Organic Pollutants on the Surface of Carbon. Environm. Sci. Tech 2: 291-297, 1968

14) Sugiura M, Esumi $K$, Meguro $K$ and Honda $H$ : Surface Treatment of meso-Carbon Microbeads by Oxygen Plasma. Bull. Chem. Soc. Jpn 58 : 2638-2640, 1985

15) Graham D: The Separate Effects of Pore Size and Surface Acidity on the Adsorbent Capacities of Activated Carbons. J. Phys. Chem 59: 896-900, 1955

16) Asakawa $T$, Ogino $K$ and Yamabe $K$ : Influence of Surface-chemical Structure of Carbon on Adsorption of Phenol. Bull. Chem. Soc. Jpn 58 : 2009-2014, 1985 
農村地域に抢ける水質保全を指向したフェノール除去に関する研究 中村武夫*, 三好 保*, 棚田成紀*, 当宮辰美*

農村地域に打ける水質保全を指向して, 排泄物の消毒に用いられるフェノールの6 種市販活性炭 による吸着除去について検討した。

表面 $\mathrm{pH}$ 10.19を示す活性炭へのフェノール吸着量は, 表面 $\mathrm{pH} 3.06$ を示す活性炭へのそれに比 べ, 平衡濃度 1 および10 ppm において，おのおの $2.17 ， 1.84$ 倍高い吸着量を示した。平衡濃度が低 い領域に打いて,フェノール吸着量は活性炭の表面 $\mathrm{pH}$ と有意な正の相関関係 $(\mathrm{p}<0.05)$ を認めた。 フェノールの活性炭に対する吸着量の差は, 活性炭の表面酸性官能基とフェノールとの相互関係 に基づくものであることが示唆された。農業排水中のフェノールを吸着除去するさいには，表面が 塩基性を示す活性炭が至適であることが判明した。

* 徳島大学医学部公衆衛生学教室

（受付：1986年10月11日）特別揭載 